\title{
Children's food allergy in Mexico
}

\author{
Alejandra Medina-Hernandez ${ }^{1 *}$, Ma del Carmen Zarate-Hernandez ${ }^{2}$, Rosa Elena Huerta-Hernandez ${ }^{3}$, \\ David Alejandro Mendoza-Hernandez ${ }^{4}$, Compedia Group ${ }^{5}$
}

From Food Allergy and Anaphylaxis Meeting 2014

Dublin, Ireland. 9-11 October 2014

\section{Background}

MexiprevAAl is a prospective cross-sectional study carried out in 2000 patients recruited in outpatient clinics. Here we present results from pediatric population.

\section{Introduction}

The aim of this nation-wide survey was to describe the profile of the patients with suspicion of food allergy seen by healthcare professionals, the normal clinical practice followed by the physicians, the social and healthcare repercussions of food allergy in Mexico.

\section{Methods}

An observational, descriptive, cross sectional study was carried out from march 2013 to march 2014 using a convenience sample of allergic patients who were treated in departments, both private and public, of physicians who ween food alley patients.

\section{Results}

Clinical, epidemiological, social data were collected from 1933 children with suspected food allergy. Preschool group was the most important followed over 14. The most suspected food was milk but the food changes with age.

\section{Discussion}

Food allergy is highly suspected in children in Mexico, specially allergy due to milk. The food involved in food allergy changes with age. the clinical presentation changes with food, although the skin was the most affected organ. Food allergy has an important impact in quality of life of patients. Even the suspicious is high the use of diagnosis resources must be improved.

'University of Queretaro, Queretaro, Mexico

Full list of author information is available at the end of the article

\section{Authors' details}

'University of Queretaro, Queretaro, Mexico. ${ }^{2}$ Hospital Universitario,

Monterrey, Mexico. ${ }^{3}$ Private Practice, Pachuca, Mexico. ${ }^{4}$ National of Pediatrics Institute, Mexico City, Mexico. ${ }^{5}$ Compedia, Colonia Nápoles, Mexico.

Published: 30 March 2015

doi:10.1186/2045-7022-5-S3-P57

Cite this article as: Medina-Hernandez et al:: Children's food allergy in Mexico. Clinical and Translational Allergy 2015 5(Suppl 3):P57.
Submit your next manuscript to BioMed Central and take full advantage of:

- Convenient online submission

- Thorough peer review

- No space constraints or color figure charges

- Immediate publication on acceptance

- Inclusion in PubMed, CAS, Scopus and Google Scholar

- Research which is freely available for redistribution
() Biomed Central

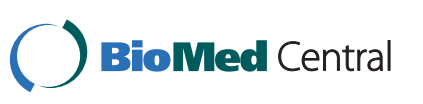

(c) 2015 Medina-Hernandez et al; licensee BioMed Central Ltd. This is an Open Access article distributed under the terms of the Creative Commons Attribution License (http://creativecommons.org/licenses/by/4.0), which permits unrestricted use, distribution, and reproduction in any medium, provided the original work is properly cited. The Creative Commons Public Domain Dedication waiver (http://creativecommons.org/publicdomain/zero/1.0/) applies to the data made available in this article, unless otherwise stated. 